\title{
Effect of Curvature on the Shear Distribution Factor for Horizontally Curved Concrete Box Girder
}

\author{
AbdulMutlib I. Said ${ }^{1}$, Hashim Khalaf Lateef ${ }^{2}$ \\ ${ }^{1}$ Department of Civil Engineering, College of Engineering, University of Baghdad, Al-Jaderia , Baghdad, Republic of Iraq \\ ${ }^{2}$ PHD student structure engineer, Baghdad-Iraq
}

\begin{abstract}
The main objective of this research is to study the effect of curvature on the shear distribution factor under the effect of AASHTO LRFD HL-93 live load for horizontally curved concrete box girder through an experimental program. The main variables considered in this study were the degree of curvature, the location of live load application and the number of the loadedlanes, under the variables the girder support reaction was measured by load cell connect to weigh indicator. The load cells and weight indicator allow calculating the shear distribution factor (SDF) according to the equilibrium method based on the girders support reaction under any load case and compared with AASHTO LRFD formulas for cast in place concrete box girder. The experimental results showed that the SDF does not affect with slight degree of curvature variation and the number of loaded lane under different radius of curvature for the exterior girder). The AASHTO formula overestimates the SDF for interior girder by $35 \%$ for straight model and overestimate by $10 \%$ for model with $\left(10^{\circ}\right)$ angle of curvature while the ASHHTO present conservative estimation for models with angle of curvature $\left(13^{0}, 18^{\circ}\right)$
\end{abstract}

Keyword: box girder, experimental program, shear distribution factor

\section{Introduction}

The geometric constrains of the urban environment and the ability of structure design tools courage the curved construction. Box girder bridges have the advantage in curved bridges due to the high torsional rigidity [11]. The additional curvature adds torsion to the system that creates significant warping and distortion stress within the member cross section furthermore the secondary member that provide stability in straight bridge became primary load carrying member in curved bridge. The load distribution factor (LDF) can consider as one of the most useful tools that allow the engineer to study bridge girder behavior by separate the effect of wheel load in the longitudinal and transverse direction. These factors have simplified The design process by allowing engineers to consider the girder design (moment \&shear) as the static (moment \& shear) caused by the AASHTO HL-93 standard truck or design lane loads as shown in Figure-1, multiplied by the LLDF calculated through AASHTO LRFD equation result that listed in Table-1 [7]. Several studies was carried out to develop an equation for the shear distribution along box girder bridges, the equation takes the form of and define Lever Rule Review and Formulas.The lever rule can be defined as approximate solution to calculate the distribution factor and the main assumption in this approximation was no transverse deck moment continuity at interior beams, which mean that the cross section of deck in transverse direction are statically determinate [10][14]. TheShear distribution factor for straight box Girder Bridge is almost uniform with increasing span length and decrease with increase in number of lanes from (2 to 3 ), this trend changes by increasing the number of lanes from ( 3 to 5 number of lanes from 2 to 3 , this trend changes by increasing the number of lanes from 3 to 5
Table 1: Shear distribution factor for cast in place concrete box girder according to AASHTO LRFD [1]

\begin{tabular}{|c|c|c|}
\hline \multicolumn{2}{|c|}{ LDF equations } & \multirow{2}{*}{$\begin{array}{c}\text { Range of } \\
\text { Applicability }\end{array}$} \\
\hline \multicolumn{2}{|c|}{ For shear in Interior Girders } & \\
\hline \multicolumn{2}{|c|}{$\begin{array}{c}\left(\frac{S}{9.5}\right)^{0.6}\left(\frac{d}{12.0 L}\right)^{0.1} \\
\text { Two or more lanes loaded } \\
\left(\frac{S}{7.3}\right)^{0.9}\left(\frac{d}{12.0 L}\right)^{0.1}\end{array}$} & $\begin{array}{c}6 \leq S \leq 18 \\
20 \leq L \leq 140 \\
18 \leq d \leq 65 \\
N C \geq 3\end{array}$ \\
\hline \multicolumn{3}{|c|}{ For shear in Exterior Girders } \\
\hline $\begin{array}{l}\text { one lane loaded } \\
L E V E R R U L E\end{array}$ & $\begin{array}{c}\text { Two or more } \\
\text { lanes loaded } \\
=e G \text { interior } \\
e=0.64+\frac{d_{e}}{12.5}\end{array}$ & $-2 \leq d e \leq 5$ \\
\hline
\end{tabular}

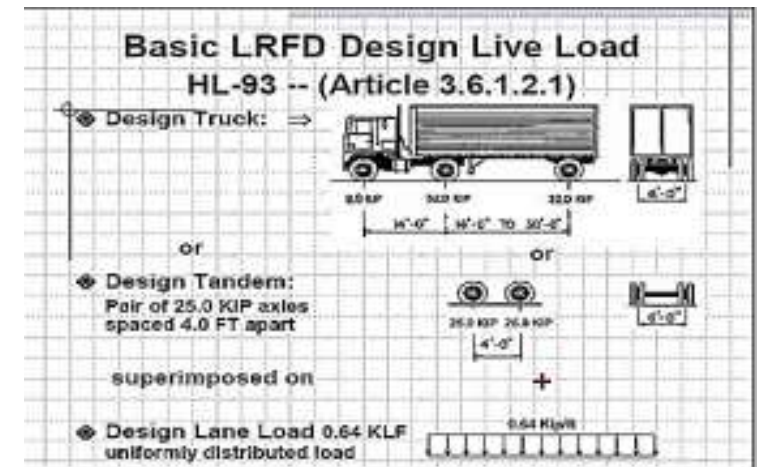

Figure 1: AASHTO LRFD HL-93 live load [1]

\section{Expermintal Program}

The experimental program includes design and construct four simply supported horizontally curved bridge models of central span of $(4000 \mathrm{~m})$ and 1400 width, three bridge models with angle and radius of curvature $\left(10^{0}, 14^{0}, 18^{0}\right)$ $((23.3,16.7,12.5 \mathrm{~m})$ and one model as straight (Reference model). The dimensions of the tested bridge model were derived by the scale down factor (1/6) from the full scale simply supported horizontally curved bridge, which were

Volume 6 Issue 12, December 2017 


\section{International Journal of Science and Research (IJSR) \\ ISSN (Online): 2319-7064}

Index Copernicus Value (2016): 79.57 | Impact Factor (2015): 6.391

designed according to AASHTO LRFD 2012 as shown in Table-2. All the tested bridge models has the same cross section as shown in Figure-2. The experimental program can be sub-divided as:- Model Construction The models construction can be classified as three stages: stage one:include preparing the mix design material test, form work, rebar for bottom slab reinforcement and end and intermediate diaphragms; vertical web reinforcement bottom slab as shown in Figure-3. Stage two includes casting the bottom slab curing reinforcement, longitudinal web reinforcement bonding, creation of the box Section as shown in Figure-4. Stage three includesLongitudinal and transverse deck slab reinforcement rebar process casting both the web and deck slab, diaphragms and curing as shown in Figure-5.

Table 2:Tested Bridge models details

\begin{tabular}{|c|c|c|c|c|}
\hline Bridge Models & $\begin{array}{c}\text { Central } \\
\text { Span }(\mathrm{m})\end{array}$ & $\begin{array}{c}\text { Radius of } \\
\text { Curvature } \\
(\mathrm{m})\end{array}$ & $\begin{array}{c}\text { Angle of } \\
\text { Curvature } \\
\text { (degree) }\end{array}$ & $(\mathrm{L} / \mathrm{R})$ \\
\hline BGS & 4.0 & 0 & 0 & 0 \\
\hline BGC23.3 & 4.0 & 23.3 & 10 & 0.171 \\
\hline BGC16.7 R16.7 & 4.0 & 16.7 & 13.5 & 0.23 \\
\hline BGC12.51R12.5 & 4.0 & 12.5 & 18 & 0.31 \\
\hline
\end{tabular}

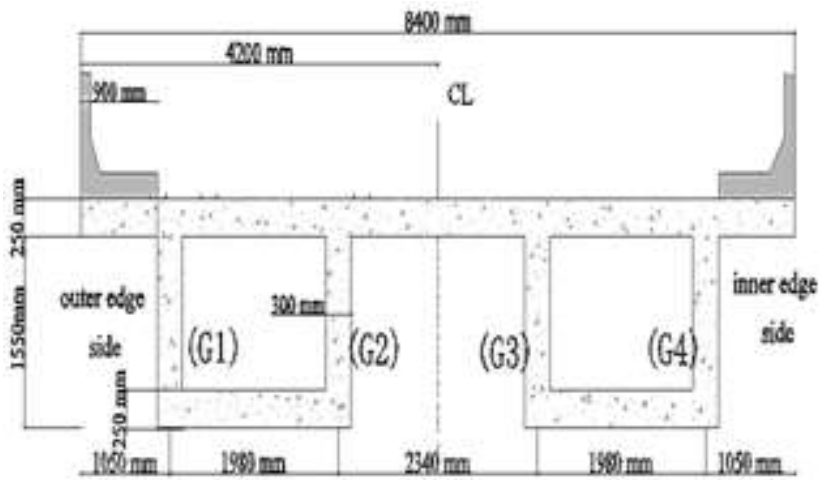

Figure 2: Bridge models cross section

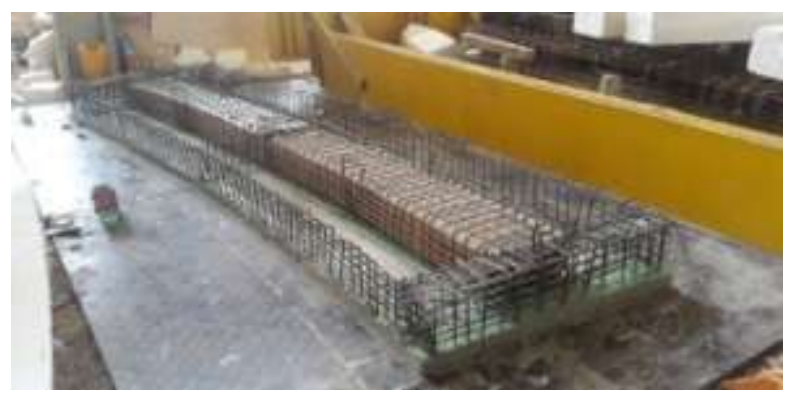

Figure 3:First stage of model construction (Model BGC R 12.5)

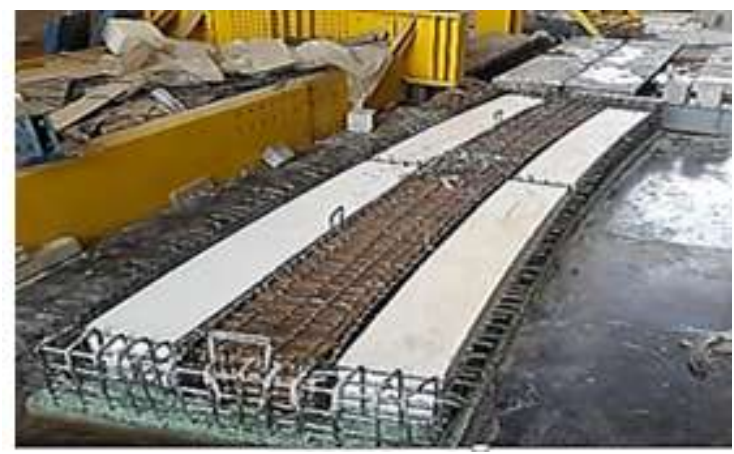

Figure 4: Second stage of model construction (Model BGC R 12.5)

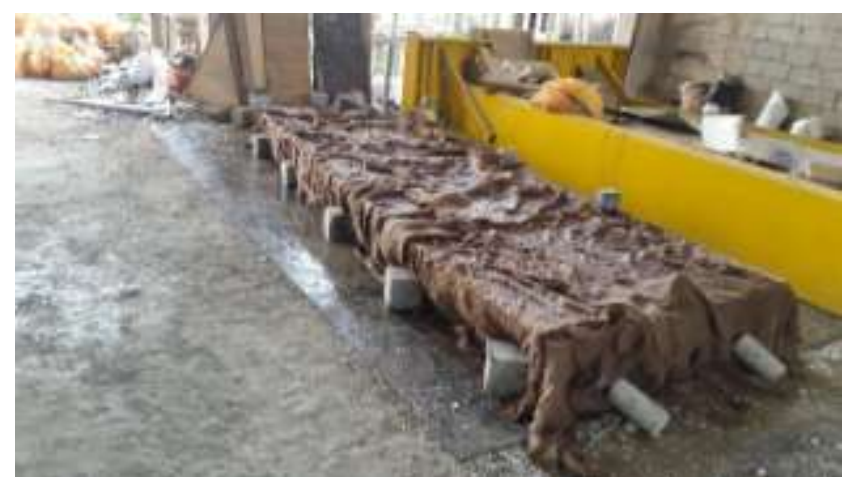

Figure 5:final stage of construction (Model BGC R 23.3)

\section{Instruments}

Eight load cells type is (low profile / Pan-cake) $5000 \mathrm{~kg}$ capacity are used to measure the reaction under each support as shown in Figure 6. Each load cell connected with a weight indicator to measure the weight or the load measured under live loadincrementfor both left and right side of the bridge girder as shown in Figure 7.

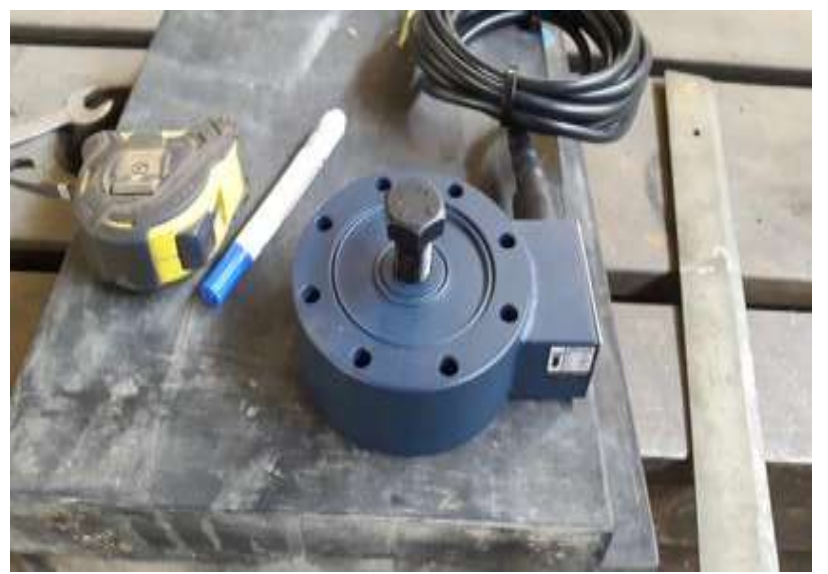

Figure 6: Load cell five-ton capacity

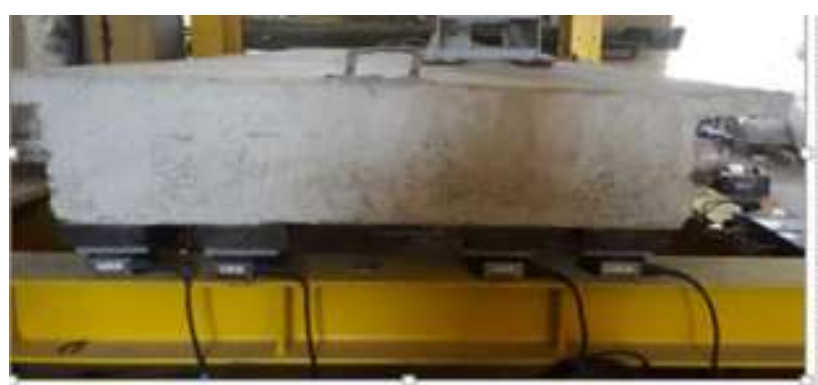

Figure 7: Load cell position under bridge girder left side

\section{Live Load Application}

In order to study the SDF, for horizontally curved box bridge. The rear wheel truck positioned in the longitudinal direction at the center of End diaphragm(width $90 \mathrm{~cm}$ center $45 \mathrm{~cm})$ prototype scaled to $1 / 6$ equal to $(15 \mathrm{~cm}$ center $7.5 \mathrm{~cm})$ as shown in Figure 8 The design truck was modeled based on real truck dimensions with the same scale factor that used for bridge cross section (1/6). the equivalent design truck modeled using two IPN-220 steel beam connect together with steel channel to ensure that the center of truck resultant

\section{Volume 6 Issue 12, December 2017}




\section{International Journal of Science and Research (IJSR) \\ ISSN (Online): 2319-7064 \\ Index Copernicus Value (2016): 79.57 | Impact Factor (2015): 6.391}

coincide with point load application as shown in Figure 9 and Figure 10 the. The total trucks scaled loadwas calculated according to the simulation requirement that given by Harry and Gajanan [4] equation for concentrated load $\mathbf{S}_{\mathbf{L}}^{\mathbf{2}}=\mathbf{1 / 3 6}$ [5], which equal to $325 \mathrm{kN}$ scaled to $10 \mathrm{kN}$ for total design truck weight scaled by (1/36). The load applied using manual hydraulic jack load and load cell as shown in Figure 16, while the design truck positioned in the transverse direction to find the maximum effect on the interior girder (G1) and represent the load case (I) "partially loaded lane" as shown in Figure 11, in the opposite side, the design truck will applied at the internal lane to represent load case(II).Finally, both lanes loaded that represent load case (III) to find the maximum effect on the interior girder (G2) as shown in Figure 12. Even the lane load that specified AASHTO HL-93 live load and was loaded during the Experimental program, only the effect of design truck will be presented in this study.

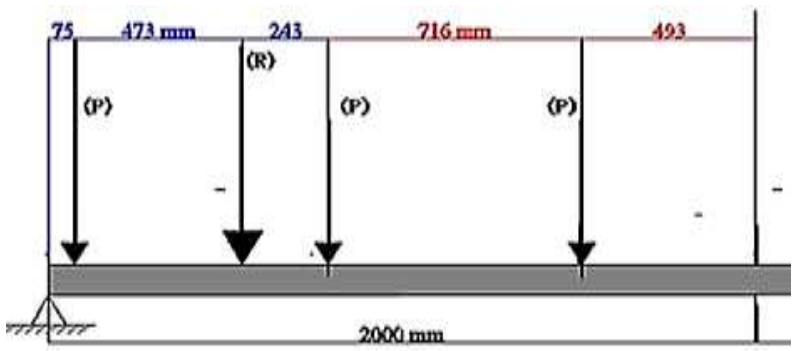

Figure 8: design truck applied at end span (longitudinal Direction)

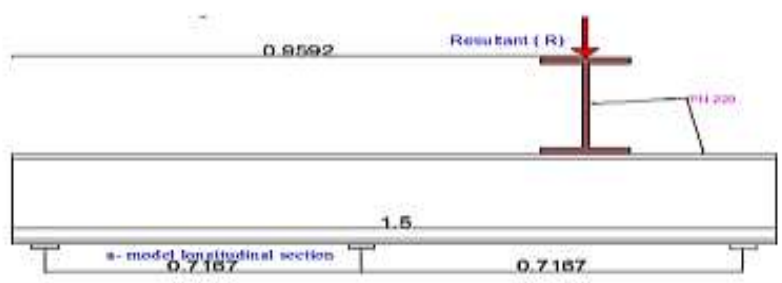

Figure 9: longitudinal section scaled design truck (1/6)

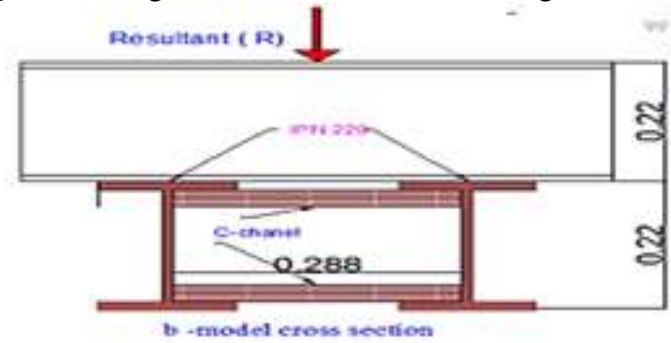

Figure 10: model cross section scaled design truck

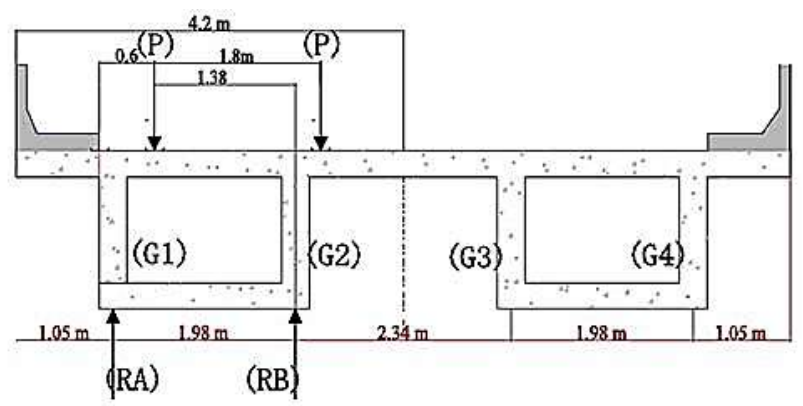

Figure 11: design truck at the transvers direction (one loaded lane) load case (I)

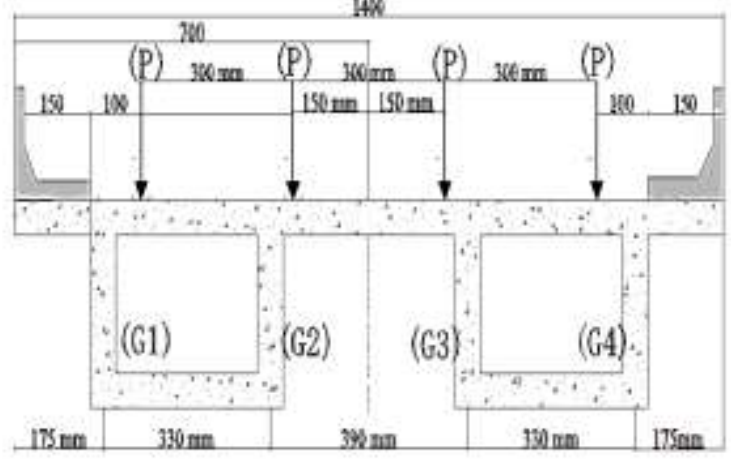

Figure 12: two-design truck (both lanes loaded)

\section{Experimental Result}

The girder (Left and Right) end span support reaction at end span load case (I,II,III) are listed in Table 3

Table 3: girder support reactionof Bridge models $(\mathrm{kN})$

\begin{tabular}{|c|c|c|c|c|c|c|c|c|c|}
\hline model & $\begin{array}{c}\text { Load } \\
\text { case }\end{array}$ & $\begin{array}{l}\text { L1 } \\
\text { G1 }\end{array}$ & $\begin{array}{l}\text { L2 } \\
\text { G2 }\end{array}$ & $\begin{array}{l}\text { L3 } \\
\text { G3 }\end{array}$ & $\begin{array}{c}\text { L4 } \\
\text { G4 }\end{array}$ & $\begin{array}{l}\text { R1 } \\
\text { G1 }\end{array}$ & R2 & R3 & R4 \\
\hline \multirow{2}{*}{ BGS } & I & 4.0 & 2.5 & 1.5 & 0.5 & 0.5 & 0.5 & 0 & 0.5 \\
\cline { 2 - 11 } & III & 4.5 & 4.0 & 4.5 & 4.0 & 0.5 & 0.5 & 1.0 & 1.0 \\
\hline BGC & I & 4.0 & 3.5 & 1.0 & 0 & 1.0 & 0.5 & 0.5 & -0.5 \\
\cline { 2 - 11 } R23.3 & III & 4.5 & 5.5 & 4.0 & 3.0 & 2.0 & 0.5 & 0.5 & 0 \\
\cline { 2 - 10 } & II & 0.50 & 1.0 & 3.0 & 3.5 & 0.5 & 0.5 & 0.5 & 0.5 \\
\hline BGC & I & 4.5 & 4.0 & 1.5 & $\mathbf{- 0 . 5}$ & 1.0 & 0.5 & 0 & $\mathbf{- 1 . 0}$ \\
\cline { 2 - 10 } R16.6 & III & 4.5 & 6.0 & 4.5 & 3.0 & 1.5 & 1.0 & 0 & -0.5 \\
\cline { 2 - 10 } & II & 0.50 & 1.5 & 3.0 & 2.5 & 1.0 & 0.5 & 0.5 & 0.5 \\
\hline BGC & I & 5.0 & 3.5 & 0.5 & 0 & 1.5 & 0.5 & 0.5 & -0.5 \\
\cline { 2 - 10 } R12.5 & III & 5.0 & 7.0 & 4.0 & 2.0 & 2.0 & 0.5 & 0 & -0.5 \\
\cline { 2 - 9 } & II & 0 & 0.5 & 4.5 & 3.5 & 0 & 0.5 & 0.5 & 0.50 \\
\hline
\end{tabular}

\section{Shear Distribution Factor (SDF)}

Depending on the total reaction listed in Table 3and based on equilibrium method,the shear distribution factor of concrete girders for the tested bridge models under (HL-93) AASHTO LRFD live load can be computed as followan listed in Tables 4 to 7

$$
(S D F)_{i}=\frac{R_{i}}{\sum_{1}^{n} R_{j} / N}
$$

Where $R_{i}$ is a maximum reaction at left or side for girder and $R_{j}$ are the specified girder bridge reaction when the truck applied at the support, $n$ is the number of the girders in the cross section and $\mathrm{N}$ is the number of loaded lane

\section{SDF for the exterior girder (G1)}

The load case (I) and (III) was chosen to select the SDF for the exterior girder as shown in Fig 13 and Fig 14

\section{SDF for the interior girder (G2)}

The load case (II) and (III) was chosen to select the SDF for the exterior girder as shown in Fig 15 and Fig 16 


\section{International Journal of Science and Research (IJSR) \\ ISSN (Online): 2319-7064}

Index Copernicus Value (2016): 79.57 | Impact Factor (2015): 6.391

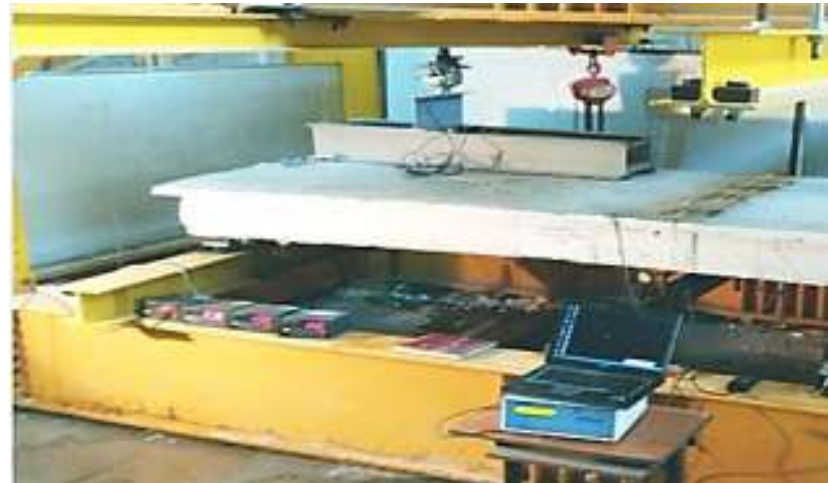

Figure 13:Design truck at the external lane load case (I)

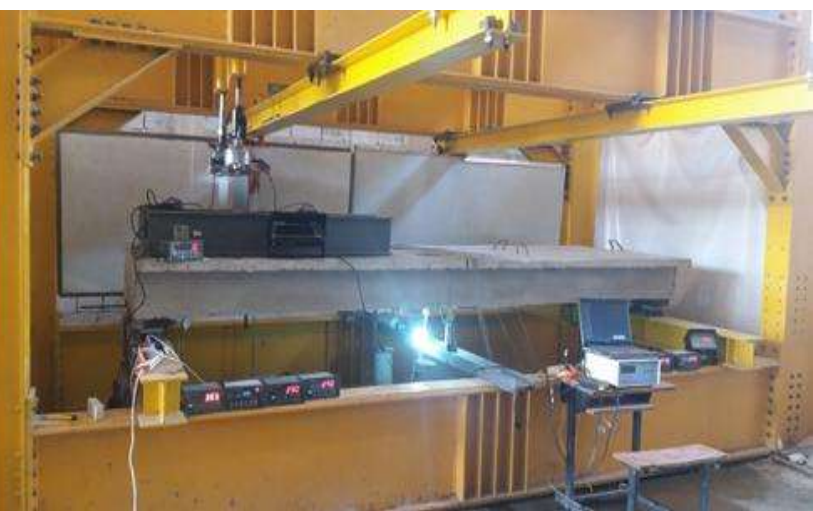

Figure 14: Two design truck at both lane (load case (III)

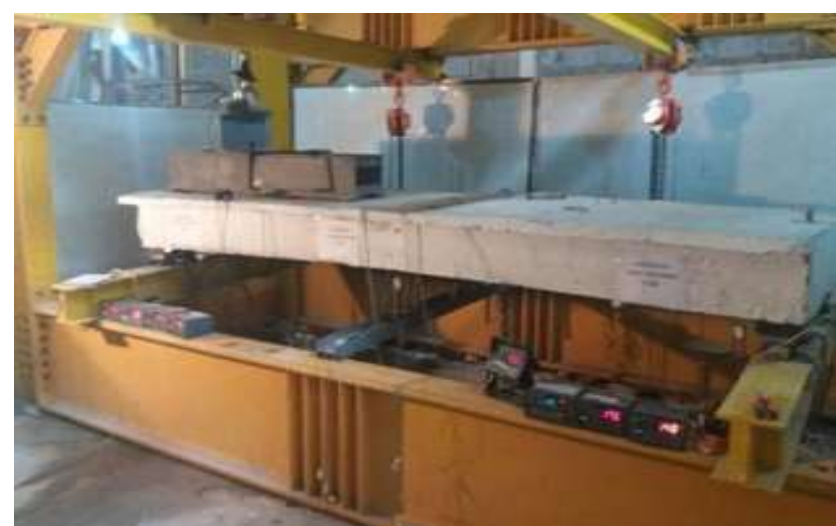

Figure-15:design truck at the internal lane load case (II)

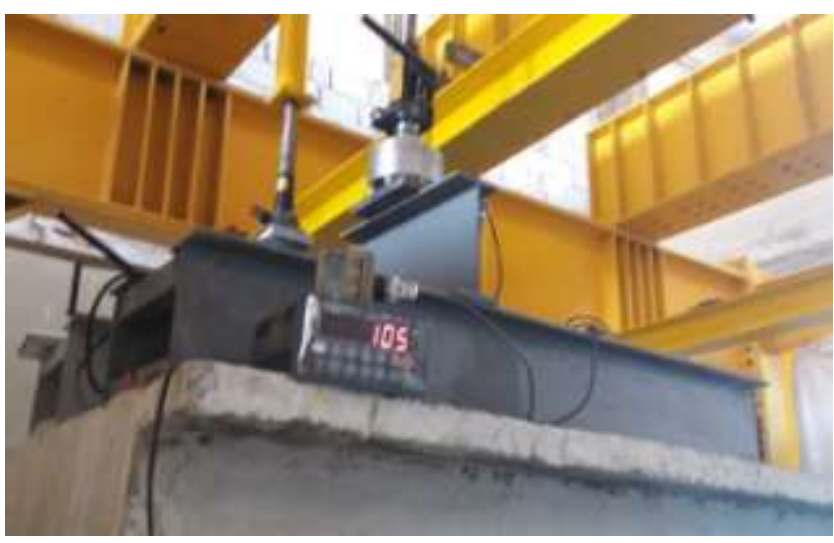

Figure 16:two design truck at end span

Table 4:SDF using Equilibrium method for model BGS

\begin{tabular}{|c|c|c|c|c|c|}
\hline Model & Load case & $G 1$ & $G 2$ & $G 3$ & G4 \\
\hline \multirow{2}{*}{ BGS } & (I) & $\mathbf{0 . 4 7}$ & 0.29 & 0.17 & 0.023 \\
\cline { 2 - 6 } & (III) & $\mathbf{0 . 5 2}$ & 0.46 & 0.52 & 0.46 \\
\hline
\end{tabular}

Table 5: SDF using Equilibrium method for model BGC R23.3

\begin{tabular}{|c|c|c|c|c|c|}
\hline Model & Load Case & G1 & G2 & G3 & G4 \\
\hline BGC & (I) & $\mathbf{0 . 4 7}$ & 0.41 & 0.11 & 0.0 \\
\cline { 2 - 6 } R23.3 & (II) & 0.1 & 0.2 & 0.4 & 0.3 \\
\cline { 2 - 6 }$\theta=13.5$ & (III) & $\mathbf{0 . 5 2}$ & $\mathbf{0 . 6 4}$ & 0.52 & 0.34 \\
\hline
\end{tabular}

Table-6: SDF using Equilibrium method for modelfor model

\begin{tabular}{|c|c|c|c|c|c|}
\hline Model & Load Case & G1 & G2 & G3 & G4 \\
\hline BGCR & (I) & $\mathbf{0 . 4 7}$ & 0.42 & 0.15 & - \\
\cline { 2 - 6 } 16.6 & (II) & 0.06 & 0.2 & 0.4 & 0.33 \\
\cline { 2 - 6 }$\theta=13.5$ & III & $\mathbf{0 . 5}$ & $\mathbf{0 . 6 6}$ & 0.5 & 0.34 \\
\hline
\end{tabular}

(-) mean negative reaction (support will upload) and the dead load will keep it position

Note:- The maximum critical SDF are shown in bold colure

Table-7: SDF using Equilibrium method for model BGC

\begin{tabular}{|l|l|l|l|l|l|}
\multicolumn{7}{c}{ R12.5 } \\
\hline Model & Load Case & G1 & G2 & G3 & G4 \\
\hline \multirow{3}{*}{$\begin{array}{l}\text { BGCR } \\
12.5\end{array}$} & (I) & $\mathbf{0 . 5 5}$ & 0.388 & 0.05 & - \\
\cline { 2 - 6 } & (II) & 0.0 & 0.05 & 0.52 & 0.41 \\
\cline { 2 - 6 } & (iii) & $\mathbf{0 . 5 4}$ & $\mathbf{0 . 7 7}$ & 0.44 & 0.22 \\
\hline
\end{tabular}

\section{ASSHTO LRFD Method}

the SDF for exterior girder can be computed using lever rule method for one loaded lane,Fig 17 shows the free-body diagram of the box girder bridge under AASHTO design truck ,Supports at $A$ and $B$ represent the exterior and adjacent interior webs of the girder .

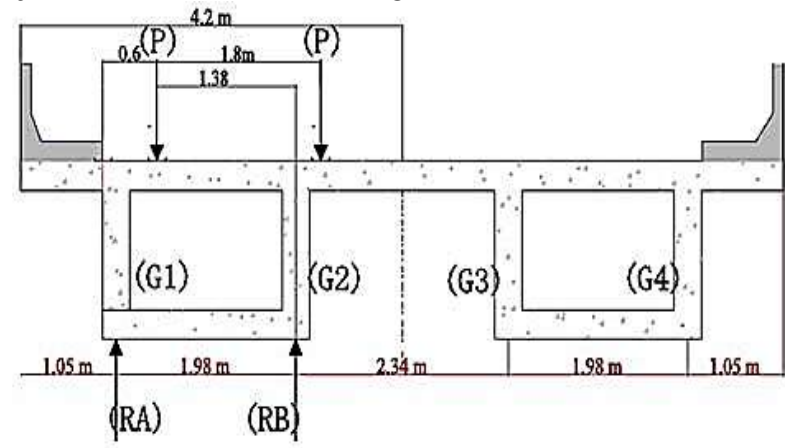

Figure 18: Testing data- load current (amperes)

The SDF for the exterior girder according to AASHTO can be computed as follow

\section{For One Design Lane Loaded by lever rule}

Calculate reaction $R A$

$\mathrm{G} 1=\mathrm{P} / 2 *[(1980-450) / 1980] * 1.2=0.464$

\section{Two or more loaded lane G interior}

Calculate the adjacent e

$$
e=0.64+\frac{d e}{3800}
$$

$d e=$ distance from the center of the exterior beam to the inside edge of the curb or barrier [ $\mathrm{ft}(\mathrm{mm})]$

$=0.64+\frac{750}{3800}=0.84$

SDF for tow loaded lane $=(\mathrm{G}$ interior $* 0.84)$

$\mathrm{G} 1=(0.702 * 0.84)=0.59$

So the SDF for exterior girder $\mathrm{G} 1=0.59$.

\section{Volume 6 Issue 12, December 2017}

\section{www.ijsr.net}




\section{International Journal of Science and Research (IJSR) \\ ISSN (Online): 2319-7064}

Index Copernicus Value (2016): 79.57 | Impact Factor (2015): 6.391

theSDF for interior girder AASHTO LRFD equations

Case 1: One design lane loaded

$$
\begin{aligned}
& \qquad S D F=\left(\frac{S}{2900}\right)^{0.6}\left(\frac{d}{L}\right)^{0.1} \\
& \left(\frac{1980}{2900}\right)^{0.6}\left(\frac{1800}{24000}\right)^{0.1}=0.616 \text { lane/web } \\
& d=\text { overall depth of a girder [ft. (mm)]. } \\
& \text { Case 2: Two or more design lanes loaded }
\end{aligned}
$$

$\left(\frac{1980}{2200}\right)^{0.9}\left(\frac{1800}{24000}\right)^{0.1}=0.702$ lane/web

$$
\begin{aligned}
& S D F=\left(\frac{S}{2200}\right)^{0.9}\left(\frac{d}{L}\right) \\
& \quad=0.702 \text { lane } / \mathrm{web} \\
& \text { rior girder } \mathrm{G} 2=0.702
\end{aligned}
$$

\section{Result Comparison}

The comparison study showed that the AASHTO equation underestimate the SDF for exterior girder (G1) when the external lane loaded by $17 \%$ for all the test bridge model except BGCR12.5 with $34 \%$ under load case (I) as shown in Table 8. when the both lanes loaded load case(III) the result compression showed that the ASSHTO LRDF overestimate the SDF for the exterior girder with $13.5 \%$ for all bridge model expect BGCR12.5 as shown in Table 10. The ASSHTO equation for overestimate the SDF for interior girder (G2) by $35 \%$ for straight model and by $10 \%$ for model with $\left(10^{0}\right)$ angle of curvature while present conservative estimation for models with angle of curvature $\left(13.5^{0}, 18^{0}\right)$ as shown in Table 10.

For these Tablesone can conclude as the angle of curvature increase the AASHTO under estimate the value of SDF.

Table 8: SDF for exterior girder under the effect of load case (I) for all the bridge models

\begin{tabular}{|c|c|c|c|c|}
\hline model & Girder & ASSHTO & $\begin{array}{c}\text { Model } \\
\text { EXP }\end{array}$ & $\begin{array}{c}\text { AASHTO } \\
\text { /EXP }\end{array}$ \\
\hline R0 & G1 & 0.464 & $0.564^{*}$ & 0.829 \\
\hline $\begin{array}{c}\text { R23.3 } \\
\theta=10\end{array}$ & G1 & 0.464 & 0.564 & 0.829 \\
\hline $\begin{array}{c}\text { R16.6 } \\
\theta=13.5\end{array}$ & G1 & 0.464 & 0.56 & 0.828 \\
\hline $\begin{array}{c}\text { R12.5 } \\
\theta=18\end{array}$ & G1 & 0.464 & 0.666 & 0.696 \\
\hline
\end{tabular}

*Reference section Reference AASHTO METHOD

* Model EXP Reference Table 7,8,9,10

$1.2=$ Multible presence factor $(\mu)$ for one lane

Table 9: SDF for exterior girder under load case (III)

\begin{tabular}{|c|c|c|c|c|}
\hline model & $\begin{array}{c}\text { Gir } \\
\text { der }\end{array}$ & AASHTO & $\begin{array}{c}\text { Model } \\
\text { EXP }\end{array}$ & $\begin{array}{c}\text { AASHTO/ } \\
\text { EXP }\end{array}$ \\
\hline R0 & G1 & 0.59 & 0.52 & 1.135 \\
\hline $\begin{array}{c}\text { R23.3 } \\
\theta=10\end{array}$ & G1 & 0.59 & 0.52 & 1.135 \\
\hline $\begin{array}{c}\text { R16.6 } \\
\theta=13.5\end{array}$ & G1 & 0.59 & 0.51 & 1.18 \\
\hline $\begin{array}{c}\text { R12.5 } \\
\theta=18\end{array}$ & G1 & 0.59 & 0.55 & 1.07 \\
\hline
\end{tabular}

* Reference AASHTO METHOD

* Model EXP Reference Table 4

$(4.50 /(4.50+6.0+4500+3000) / 2) * 1=0.5$

$1.0=$ Multible presence factor $(\mu)$ for one lane
Table 10: SDF for interior girder under load case (III)

\begin{tabular}{|c|c|c|c|c|}
\hline Model & Girder & AASHTO* & Model EXP & AASHTO/EXP \\
\hline R0 & G3 & 0.702 & 0.52 & 1.35 \\
\hline R23.3 & G2 & 0.702 & 0.64 & 1.09 \\
$\theta=10$ & & & & \\
\hline R16.6 & G2 & 0.702 & 0.66 & 1.06 \\
$\theta=13.5$ & & & & \\
\hline R12.5 & G2 & 0.702 & 0.77 & 0.92 \\
$\theta=18$ & & & & \\
\hline
\end{tabular}

* Reference AASHTO METHOD

* Model EXP Reference Table 4

$(7.0 /(5.0+7.0+4.0+2.0) / 2)) * 1=0.77$

$1.0=$ Multible presence factor $(\mu)$ for one lane

\section{Conclusion}

1) The generated support reaction for both left and right girder under HL-93 live load is equal to the applied loads, which mean the measuring processor is correct

2) The experimental result showed that the shear distribution factor does not affect with slight degree of curvature variation under load case (I) for the exterior girder $(\mathrm{G} 1)$ by $(0 \%, 0 \%, 17 \%)$ if compared with straight models

3) The experimental result showed that the shear distribution factor change with the number of loaded lane under different radius of curvature for the exterior girder (G1) $(19 \%, 24 \%, 49 \%)$ if compared with straight models

4) The experimental result showed that the shear distribution factor increased when the curvature increased for the exterior girder (G1)

5) 5-The ASSHTO equation for estimation the SDF for interior girder (G2) overestimate the SDF by $35 \%$ for straight model and overestimate by $10 \%$ for model with $\left(10^{\circ}\right)$ angle of curvature while present conservative estimation for models with angle of curvature $(13,18)$

6) simple Girder tilting (uplift) was measured under the load case (I) in the right side equal to $(0.5 \mathrm{kN})$ at inner edge girder (G4) for each (1 Ton) under load case (I)

\section{References}

[1] American Association of State Highway and Transportation Officials, AASHTO. 2012. Standard Specifications for Highway Bridges. Washington, D.C AASHTO LRFD Bridge Design Specification, Sixth edition, 2012

[2] Ayman R. M. "Experimental and Theoretical Studies of Horizontally Curved Reinforced Concrete Multi-Spine Bridge" Thesis submitted in Civil Engineering Dept., University of Baghdad-Iraq in a partial fulfillment of the requirements for the degree of thedegreeofdoctor ofphilosophy in civil engineering, 2016.

[3] Caltrans, Bridge Design Practice, California Department of Transportation, Sacramento, CA (2014

[4] Dereck J. Hodson“ Live Load Test and Finite Element Analysis of a Box Girder Bridge for the Long Term Bridge Performance Program" thesis submitted in partial fulfillment of the requirements for 
the degree of master of science in Civil and Environmental Engineering: Utah State University

[5] Harry G. Harris and Gajanan M. Sabnis "Structural Modeling and Experimental Techniques" Second Edition, 1999.

[6] ImadEldinKhalafalla and Khaled Sennah "Curvature Limitations For Concrete Box-Girder And Solid Slab Bridges" ACI Structural Journal Volume: 111, Issue: 5, ( 2015

[7] Manal Ibrahim “ Investigation of Load Distribution Factors for Two-Span Continuous Composite Multiple Box girder Bridges " A Thesis Present to Ryerson University In partial fulfillment of the Requirement for the Degree of Master of Applied Science In the program of Civil Engineering Toronto, Ontario, Canada 2012

[8] Mohammed Zaki“ Live Load Distribution Factors For Horizontally Curved Concrete Box Girder Bridges" Submitted to the Graduate School of the University Of Massachusetts Amherst in partial fulfillment of the requirement for the degree of master of science in civil engineering 2016

[9] Narendra Taly "Design of Modern Headway Bridges", McGraw Hill, 1998.text book Standardization (CEN) Brussels, Belgium.

[10] National Corporative Highway Research Program (NCHRP Report 592), " Simplified Live Load Distribution Factor Equations" Transportation Research Board of the National Academies, , 2007 , WASHINGTON, D.

[11] Sennah, K., and Kennedy, J. 2001!. "'State-of-theart in design of curved box-girder bridges.' J. Bridge Eng., 6 3!, 159-1678

[12] Washington State Department of Trans."WSDOT "Bridge Design Manual (LRDF)." Bridge and Structure Office, Chapter. 5,

[13] Wai-Fah Chen and LianDuan"Bridge Engineering Handbook" Boca Raton London New York Washington, D. C. 2000 by CRC Press LLC 